\title{
ANALISIS SOAL TOSA (TEST OF STANDARD ARABIC) MENGACU PADA CEFR (COMMON EUROPEAN FRAMEWORK OF REFERENCE FOR LANGUAGE)
}

\author{
Muhammad Zaenuri, Muhammad Nur Kholis, Anisatul Barokah \\ Institut Agama Islam Negeri Surakarta \\ email: zaenuri_eljawiy@yahoo.com
}

\begin{abstract}
This study aims to explore and analyze the TOSA (Test of Standard Arabic) questions as an instrument to measure the Arabic language competence of students at IAIN Surakarta. This research uses a qualitative approach. The results of the study showed: 1) TOSA was prepared using an integrative, communicative and pragmatic approach; 2) TOSA is a type of standard test used to measure the Arabic language competency testee, not the testee's mastery of the material that has been taught; 3) TOSA competency standard refers to CEFR (Common European Framework of Reference for Language) according to its part, so fahmu al-masmu 'is equivalent to A1-C1 CEFR, fahmu at-tarakib allughawiyyah is equivalent to A1-B2 CEFR, and fahmu al-maqru' is equivalent to Al-Cl CEFR.
\end{abstract}

Keywords: CEFR; Language Competency; Language Test Approach;

Standardized Test.

\begin{abstract}
Abstrak
Penelitian ini bertujuan untuk mendeskripsikan dan menganalisis soal TOSA (Test of Standard Arabic) sebagai instrumen untuk mengukur kompetensi Bahasa Arab mahasiswa di IAIN Surakarta. Penelitian ini menggunakan pendekatan kualitatif. Hasil penelitian menunjukan: 1) TOSA disusun dengan menggunakan pendekatan integratif, komunikatif dan pragmatik; 2) TOSA termasuk jenis tes standar yang digunakan untuk mengukur kompetensi berbahasa Arab testee, bukan penguasaan testee terhadap materi yang telah diajarkan; 3) standar kompetensi TOSA mengacu pada CEFR (Common European Framework of
\end{abstract}


Reference for Language) menurut bagiannya maka fahmu al-masmu' setara dengan A1-C1 CEFR, fahmu at-tarakib al-lughawiyyah setara dengan A1-B2 CEFR, dan fahmu al-maqru' setara dengan B1-Cl CEFR.

Kata Kunci: CEFR; Kompetensi Bahasa; Pendekatan Tes Bahasa; Tes Standar.

\section{A. Pendahuluan}

Tes Bahasa sebagai salah satu alat ukur kompetensi Bahasa testee memiliki peranan yang sangat penting, selain memberikan informasi tentang keberhasilan proses pembelajaran, juga sebagai bahan refleksi terhadap kualitas tes itu sendiri. Sebagai alat ukur, tes harus memiliki keakuratan dalam mengukur, sehingga hasil tes benar-benar menggambarkan kompetensi yang diinginkan. Maka dalam penyusunannya harus memperhatikan standar tes yang baik, meliputi validitas, reliabilitas, tingkat kesulitan dan daya beda yang baik. ${ }^{1}$

Berbeda dengan tes pengetahuan, tes bahasa memiliki karakteristik yang berbeda. Hal ini dikarenakan tes Bahasa tidak hanya mengukur pengetahuan tentang Bahasa tetapi juga kompetensi menggunakan Bahasa dan bagaimana Bahasa digunakan. Sehingga dalam menentukan model tes bahasa selalu didasari pada landasan filosofis yang berkaitan dengan berbagai pendekatan tes bahasa yang akan digunakan sebagai landasan dalam menyusun tes. ${ }^{2}$ Sehingga isi dan jenis tes Bahasa sangat ditentukan oleh bagaimana Bahasa dipahami dengan berbagai disiplin ilmu seperti linguistik, psikolinguistik, sosiolinguistik dan hal lain yang berhubungan dengan pembelajaran Bahasa.

Selain model tes, hal penting yang harus diperhatikan adalah acuan yang digunakan dalam menyusun tes. Lebih-lebih apabila jenis tes yang dikembangkan merupakan tes standar, maka tes yang dikembangkan harus mengacu pada standarisasi yang dibuat oleh lembaga yang berwenang untuk itu. Di antara standar kompetensi Bahasa yang dikembangakan oleh para ahli Bahasa yaitu Al-Ithar Al-Marja'i Al-Eropa Al-Musytarak atau biasa disingkat dengan CEFR (Common European Framework of Reference for Language), Ma'ayiir Al-Majlis Al-Amriki Li Al-Lughaat atau ACTFL (American Council for the Teaching of Foreign Languages), dan Ma'aayiiru At-Thaawilah Al-Mustadirah atau ILR (Interagency Language Roundtable). ${ }^{3}$

\footnotetext{
${ }^{1}$ Moh. Ainin, "Kesahihan Dalam Penyusunan Tes Bahasa Arab Di Madrasah/Sekolah," Prosiding Konferensi Nasional Bahasa Arab 2 (2016): 291-303, http://prosiding.arab-um.com/index.php/konasbara/article/view/75.

${ }^{2}$ M. Soenardi Djiwandono, Tes Bahasa Dalam Pengajaran (Bandung: ITB Press, 1996), 1-8.

${ }^{3}$ Tulus Musthofa, "Al-Ithaar Al-Marja'iy Al-Induniisiy Li Ta'liimi Al-Lughah Al'Arabiyyah Fi Dhaui Al-Ithar Al-Marja'ly Al-Eropa Al-Musytarak Li Ta'limi Al-Lughaat," Prosiding Pertemuan IImiah Internasional Bahasa Arab XI (2018): 1159, http://prosiding.imla.or.id/index.php/pinba/article/view/98.
} 
CEFR menjadi salah satu acuan dalam pemetaan kompetensi bahasa asing yang telah digunakan dan diakui oleh masyarakat internasional. CEFR membagi kompetensi berbahasa asing menjadi 6 level, yaitu A1, A2, B1, B2, $\mathrm{C} 1$, dan $\mathrm{C} 2 .{ }^{4}$ Adanya standarisasi seperti ini tentu akan memudahkan bagi pihak yang berkepentingan untuk melihat kualifikasi bahasa seseorang. Apabila kita lihat beberapa situs pada Arabic Level Test online seperti toafl.com; arabiconline.eu; learning.aljazeera.net; ArabicWorkshop.com; mereka telah menggunakan CEFR sebagai acuan dalam menentukan kualifikasi. Hal ini menunjukan adanya perkembangan dalam penyusunan tes standar bahasa Arab di dunia.

Namun begitu, sampai saat ini belum ada satu format standar yang diakui oleh seluruh dunia sebagaimana TOEFL pada tes bahasa inggris. Namun disisi lain perguruan tinggi islam seperti STAIN, IAIN dan UIN membutuhkan satu alat tes standar yang dapat mengukur kompetensi bahasa Arab mahasiswanya. Sehingga munculah tes bahasa Arab standar yang dikembangkan oleh masing-masing perguruan tinggi islam, seperti TOAFL di UIN Jakarta, IKLA' di UIN Yogyakarta, ILAiK di IAIN Salatiga. Sebagaimana disebutkan oleh Muhbib bahwa gagasan melakukan standarisasi kompetensi berbahasa Arab bagi lulusan PTAIN sudah lama muncul namun nyatanya belum ada kesepakatan hingga sekarang. ${ }^{5}$ Tidak adanya satu kesepakatan antara perguruan tinggi baik perguruan tinggi islam maupun perguruan tinggi umum yang memiliki program Bahasa Arab serta lembaga-lembaga pengembangan Bahasa Arab di luar perguruan tinggi, menyebabkan standar tes tersebut tidak memiliki persamaan antara tes yang dikembangkan oleh satu lembaga dengan lembaga yang lain.

Dalam penelitian tentang standarisasi kompetensi bahasa Arab, ditemukan bahwa Bahasa Arab di UIN Jakarta dan UIN Yogyakarta dititikberatkan pada kompetensi membaca dan memahami teks-teks keagamaan yang sesuai dengan keilmuan-keilmuan di prodi dan fakultas. Bukan tanpa alasan, karena bahasa Arab sebagai media utama dalam kajian islam. ${ }^{6}$ Dengan temuan ini tentu berimplikasi terhadap model dan konten tes bahasa Arab di kedua UIN tersebut.

${ }^{4}$ Council of Europe, "Common European Framework of Reference for Languages: Learning, Teaching, Assesment" (Language Policy Unit, Strasbourg), diakses 23 Desember 2020, https://rm.coe.int/16802fc1bf.

${ }^{5}$ Muhbib Abdul Wahab, Perkembangan Tes Bahasa Arab Standar Di Indonesia (Jakarta: repository.uinjkt.ac.id, 2017), http://repository.uinjkt.ac.id/dspace/bitstream/123456789/33917/1/Muhbib_1.pdf.

${ }^{6}$ Muhbib Abdul Wahab dkk., "Standarisasi Kompetensi Bahasa Arab Bagi Calon Sarjana Perguruan Tinggi Keagamaan Islam Negeri," Arabiyat : Jurnal Pendidikan Bahasa Arab dan Kebahasaaraban 5, no. 1 (2018): 38-64, https://doi.org/10.15408/a.v5i1.6691. 
IAIN Surakarta sebagai salah satu PTKIN di Indonesia mengembangkan tes standar bahasa Arab yang diberi nama TOSA (Test Of Standard Arabic). TOSA sebagai tes kompetensi dikembangkan berdasarkan standar kompetensi yang ditetapkan oleh PPB IAIN Surakarta. Hal ini tentu perlu diteliti dan dianalisis lebih jauh bagaimana standar yang telah ditetapkan dalam mengembangkan soal-soal TOSA apabila disandingkan dengan $C E F R$ sehingga diketahui level TOSA mengacu pada CEFR.

Penelitian terkait tentang $C E F R$ banyak dilakukan oleh peneliti-peneliti terdahulu, seperti yang dilakukan oleh J Charles Alderson, dkk, dari hasil penelitiannya menjelaskan bahwa mengidentifikasi tingkat CEFR yang terpisah setidaknya merupakan suatu problematika empiris dalam menentukan konten tes, spesifikasi tes, dan identifikasi oleh sistem klasifikasi atau kisi-kisi konten. ${ }^{7}$ Penelitian lain juga dilakukan oleh Jana Bérešová tentang dampak $C E F R$ pada pengajaran dan tes Bahasa inggris di Slovakia. Hasil penelitiannya menemukan bahwa sangat penting memahami deskripsi $C E F R$ dan sampel yang ilustratif untuk menerapkan CEFR yang efektif. ${ }^{8}$ Pada penelitian lain juga ditemukan bahwa para penilai menerjemahkan berbeda pada setiap deskripsi kompetensi Bahasa yang ditetapkan oleh CEFR dengan penilaian mereka. Hal ini menimbulkan masalah pada validitas yang kurang selaras dengan ketentuan tersebut, sehingga hasil penilain kurang valid. ${ }^{9}$

Berbeda dengan penelitian-penelitian sebelumnya, penelitian ini bertujuan menganalisis level TOSA dengan mengacu pada CEFR. Selain tujuan tersebut penelitian ini juga akan melihat model soal TOSA dilihat dari pendekatan tes Bahasa dan jenis soal Bahasa Arab pada TOSA. Dari hasil analisis ini akan diketahui bahwa TOSA layak sebagai tes standar yang berkualitas yang dapat mengukur kompetensi bahasa Arab dengan tepat.

\section{B. Metode Penelitian}

Penelitian ini menggunakan pendekatan kualitatif, yakni penelitian yang pengumpulan datanya bersifat kualitatif yang berupa lisan atau tulisan dan benda-benda yang diamati secara detail sehingga dapat ditangkap makna

7 J. Charles Alderson dkk., "Analysing Tests of Reading and Listening in Relation to the Common European Framework of Reference: The Experience of The Dutch CEFR Construct Project," Language Assessment Quarterly 3, no. 1 (2006): 3-30, https://doi.org/10.1207/s15434311laq0301_2.

8 Jana Bérešová, "The Impact of the CEFR on Teaching and Testing English in the Local Context," Theory and Practice in Language Studies 7, no. 11 (2017): 959, https://doi.org/10.17507/tpls.0711.03.

${ }^{9}$ Claudia Harsch dan Johannes Hartig, "What Are We Aligning Tests to When We Report Test Alignment to the CEFR?," Language Assessment Quarterly 12, no. 4 (2015): 333, https://doi.org/10.1080/15434303.2015.1092545. 
yang tersirat dalam dokumen atau benda tersebut. ${ }^{10}$ Sedangkan dilihat dari jenis penelitiannya merupakan penelitian kepustakaan. Penelitian kepustakaan adalah jenis penelitian yang identic dengan kegiatan analisis teks atau wacana untuk mendapatkan fakta-fakta yang tepat. ${ }^{11}$

Sumber data dalam penelitian ini terdiri dari: 1) Sumber data primer adalah data pokok yang berasal dari sumber asli yang digunakan untuk menjawab penelitian. Data primer dalam penelitian ini adalah soal tes pada buku Al Mahir Jilid 1 dan 2; 2) Data sekunder adalah data pendukung yang berbentuk buku dan dokumen lain yang digunakan dalam penelitian kepustakaan. Data sekunder dalam penelitian ini berupa buku, artikel dan jurnal yang membahas tentang tes bahasa dan $C E F R$, dan dokumen-dokumen lainnya yang dapat digunakan sebagai pendukung penelitian ini.

\section{Hasil Penelitian dan Pembahasan}

\section{Pendekatan Tes Bahasa Pada TOSA}

Pendekatan tes Bahasa adalah suatu cara pandang yang mempengaruhi bagaimana keterampilan berbahasa dan materi kebahasaan disajikan ke dalam butir-butir soal tes. Ada beberapa pendekatan diantaranya yaitu pendekatan diskret, pendekatan integratif, pendekatan pragmatik, pendekatan komunikatif, dan pendekatan autentik. ${ }^{12}$

Keterampilan berbahasa yang meliputi istima', kalam, qira'ah, kitabah dan juga unsur-unsur pendukungnya seperti kosakata dan tata Bahasa dapat di-tes-kan secara terpisah maupun terpadu. Tes keterampilan Bahasa maupun unsur Bahasa yang menyajikan secara terpisah setiap keterampilan atau unsur Bahasa merupakan tes dengan pendekatan diskret. Sedangkan tes yang menyajikan soal yang mencakup semua unsur keterampilan Bahasa dan unsur Bahasa merupakan tes dengan pendekatan integrasi. Tes bahasa dengan pendekatan diskret dilakukan untuk menilai secara khusus satu keterampilan atau unsur bahasa sesuai dengan kriteria keterampilan yang dinilai. Sedangkan tes dengan pendekatan integrasi dilakukan untuk menilai kemampuan berkomunikasi secara autentik dengan melibatkan semua keterampilan bahasa. Pendekatan diskret dalam tes bahasa didasarkan pada pendekatan linguistik struktural yang menganggap bahwa bahasa sebagai satu lingual yang terdiri dari bagian-bagian yang tertata menurut struktur tertentu. Sedangkan pendekatan tes integrasi didasarkan pada pandangan

\footnotetext{
${ }^{10}$ Suharsini Arikunto, Prosedur Penelitian: Suatu Pendekatan Praktik (Jakarta: Rineka Cipta, 2013), 22.

${ }^{11}$ Amir Hamzah, Metode Penelitian Kepustakaan (Malang: Literasi Nusantara, 2020), 7.

${ }^{12}$ Abdul Munip, Penilaian Pembelajaran Bahasa Arab (Yogyakarta: FITK UIN Sunan Kalijaga, 2017), 106.
} 
bahwa berbahasa adalah penggabungan semua unsur bahasa agar diperoleh kesatuan makna dalam dalam proses komunikasi. ${ }^{13}$

Selain pendekatan diskrit dan integratif, dalam tes bahasa juga terdapat pendekatan pragmatik dan pendekatan komunikatif. Pendekatan pragmatik adalah pendekatan yang melihat bahwa pemahaman terhadap teks yang disampaikan tidak diperoleh hanya sekedar melalui unsur yang ada dalam bahasa tetapi juga konteks di luar linguistik yang membentuk teks tersebut. Soal tes dengan pendekatan ini digunakan untuk mengukur seberapa baik pembelajar bahasa menggunakan elemen-elemen bahasa sesuai konteks berbahasa yang sesungguhnya.

Sedangkan pendekatan komunikatif berpandangan bahwa pembelajaran bahasa harus sesuai dengan fungsi-fungsi Bahasa untuk keperluan komunikatif baik komunikasi yang bersifat aktif-reseptif (istima' dan kalam) maupun aktif-produktif (kalam dan kitabah). Tes bahasa dengan pendekatan komunikatif melibatkan semua aspek bahasa sebagaimana seseorang berkomunikasi yang melibatkan semua unsur kebahasaan. Sehingga bentuk tes komunikatif berupa tes kemampuan berbahasa sebagaimana bahasa digunakan dalam konteks yang jelas. ${ }^{14}$ Ada beberapa ciri pendekatan komunikatif, diantaranya yaitu :

a. Topik dan konten beragam sesuai dengan tujuan tes.

b. Sumber pemilihan bahan penguasaan Bahasa yang diorientasikan pada masalah bidang untuk program akademik, dan yang diorientasikan pada masalah penggunaan Bahasa sehari-hari untuk linguistik survival

c. Konten tes bersumber dari berbagai referensi seperti buku, jurnal, majalah, surat kabar.

d. Jenis dan format tes bisa berbentuk objektif maupun subjektif. ${ }^{15}$

Selain pendekatan-pendekatan tersebut, terdapat pula pendekatan pragmatik dan pendekatan otentik. Pendekatan pragmatik dalam tes bahasa sama dengan pendekatan komunikatif, yang menekankan pada bagaimana tes dapat mengukur kemampuan berbahasa secara nyata sebagaimana bahasa tersebut digunakan. Pendekatan ini berpandangan bahwa bahasa merupakan alat berkomunikasi, maka seseorang dinyatakan memiliki kompetensi bahasa apabila mampu menggunakan bahasa sesuai dengan konkteks yang sesungguhnya, sehingga tes dengan pendekatan ini tidak hanya mengukur pemahaman linguistik tapi juga ekstralinguistik. Dalam penyajiannya, tes dengan pendekatan ini tidak ada tes kosakata dan tatabahasa secara

${ }^{13}$ M. Zaim, Evaluasi Pembelajaran Bahasa Inggris (Jakarta: Kencana, 2016), 100-

102.

${ }^{14}$ Munip, Penilaian Pembelajaran Bahasa Arab, 124-25.

${ }^{15}$ Ahmad Muradi, Pembelajaran Menulis Bahasa Arab : Dalam Perspektif Komunikatif (Jakarta: Kencana, 2015), 55. 
tersendiri, tetapi semua unsur kebahasaan disajikan bersamaan sekaligus dengan ekstralinguistik. ${ }^{16}$

Sedangkan tes dengan pendekatan otentik merupakan tes yang dilakukan untuk menilai proses dan hasil sekaligus. Pendekatan ini sejalan dengan teori Bloom yang berpandangan bahwa penilaian harus mencakup ranah kognitif, afektif, dan psikomotorik. Pendekatan ini lebih melihat kompetensi komunikatif daripada kompetensi linguistik. Dengan demikian, soal tes bahasa menggunakan pendekatan ini menilai ketepatan penggunaan bahasa sekaligus juga ketepatan kebermaknaan bahasa yang sesuai dengan realitas kehidupan berbahasa di masyarakat. ${ }^{17}$

Dari berbagai pendekatan tes bahasa tersebut dapat digunakan sebagai pijakan dalam menentukan model tes yang akan dikembangkan tergantung pada tujuan daripada tes yang dilakukan. Dari pemahaman berbagai pendekatan tes bahasa tersebut sebenarnya ada kesamaan, sehingga satu pendekatan dapat disandingkan dengan pendekatan lainnya dalam mengembangkan tes, seperti tes pragmatik, komunikatif dan otentik memiliki banyak kesamaan. Tes diskret pun juga bisa digunakan secara berdampingan dengan tes otentik.

Apabila dianalisis dari sudut pendekatan tes bahasa, soal-soal pada TOSA merupakan soal tes bahasa dengan pendekatan integratif. Hal ini dapat dilihat pada beberapa soal yang terdapat pada soal latihan TOSA. Pada bagian fahmul masmu' misalnya, terdapat soal seperti berikut ${ }^{18}$ :

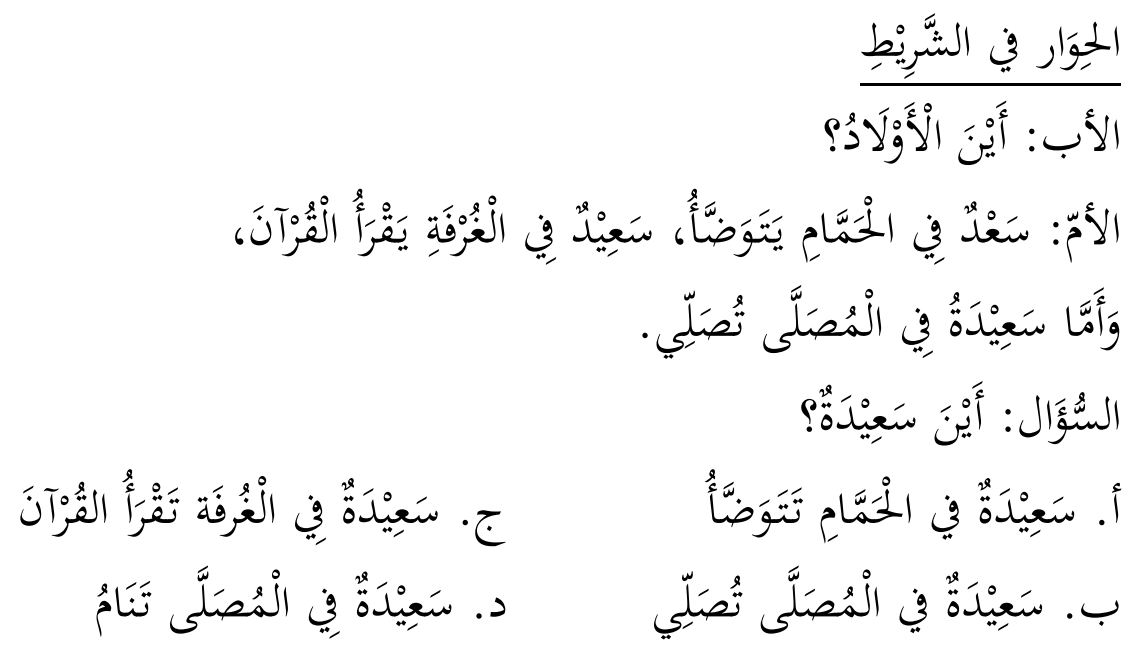

Pada contoh soal diatas tampak bahwa soal tersebut digunakan untuk mengukur pemahaman testee terhadap wacana singkat yang didengar pada

${ }^{16}$ Munip, Penilaian Pembelajaran Bahasa Arab, 114.

${ }_{17}$ Munip, 125.

${ }^{18}$ Abdullah Faishol, Al-Mahir fi Tathbiqi Maharati al-Istima' wa al-Kalam (Surakarta: P2B IAIN Surakarta, 2019). 
soal fahmul masmu'. Untuk bisa memahami wacana lisan yang didengar tersebut, testee perlu memahami mufradat yang digunakan dalam khiwar tersebut. Dengan demikian, contoh soal diatas tersebut termasuk dalam kategori tes integratif yang mengukur kemampuan istima' dan mufradat.

Pada bagian lain tentang fahmut tarakib al-'arabiyyah, juga menggunakan pendekatan integratif. Sebagaimana contoh soal TOSA berikut

$$
\begin{aligned}
& \text { التوجيه: اختر الكلمة المناسبة بين (أ)، (ب)، (ج)، و (د) للجمل الآتية! }
\end{aligned}
$$

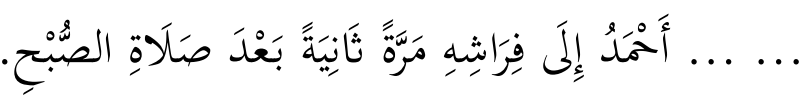

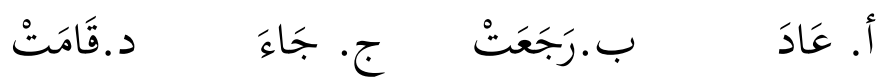

Pada soal di atas menunjukan butir soal tes dengan pendekatan integratif yang mengukur pemahaman dan kemampuan testee tentang qawa'id nahwiyah tentang susunan fi'il dan fa'il yang mensyaratkan kesesuaian antara mudzakar atau muanats diantara keduanya. Selain pemahaman qawa'id nahwiyah, soal diatas juga mengukur kemampuan testee menggunakan mufradat sesuai dengan konteks yang tepat sebagaimana yang dimaksudkan pada kalimat diatas.

Soal TOSA yang menggunakan pendekatan integratif juga ditemui pada bagian fahmul maqru', seperti soal TOSA berikut ini:

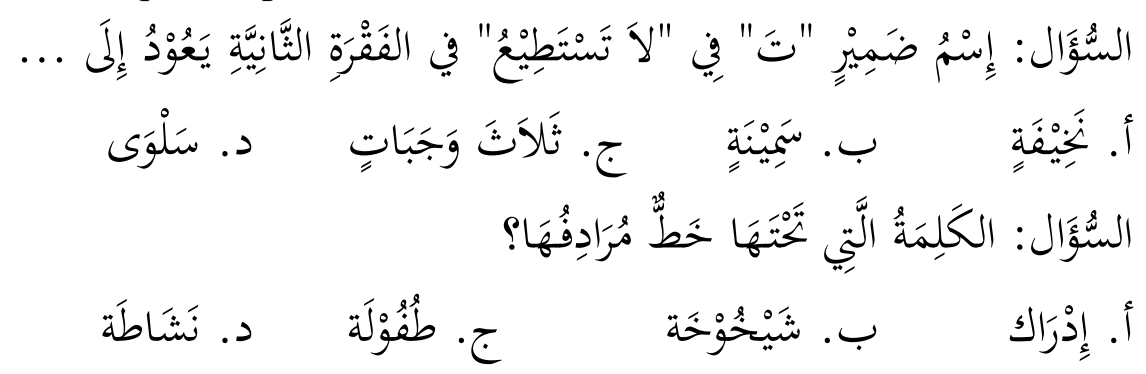

Pada contoh soal diatas keduanya merupakan tes integratif. Pada soal pertama digunakan untuk mengukur kemampuan testee dalam memahami qawa'id nahwiyah dan memahami isi teks sekaligus. Sedangkan pada soal kedua digunakan untuk mengukur pemahaman testee tentang mufradat dan juga pemahaman testee terkait teks yang membangun pemahaman mufradat tersebut.

Selain pendekatan integratif, soal TOSA juga menggunakan pendekatan komunikatif dan pendekatan pragmatik. Sebagaimana dijelaskan pada penjelasan sebelumnya, kedua pendekatan ini memiliki kesamaan, yaitu sama-sama menekankan pada kemampuan berbahasa dalam situasi riil dan nyata. Semua soal pada setiap bagian pada soal TOSA merupakan tes yang mengukur kemampuan atau pemahaman testee dalam menggunakan bahasa 
dalam konteks yang jelas. Model soal TOSA yang menggambarkan pendekatan ini seperti butir soal tes berikut ini:

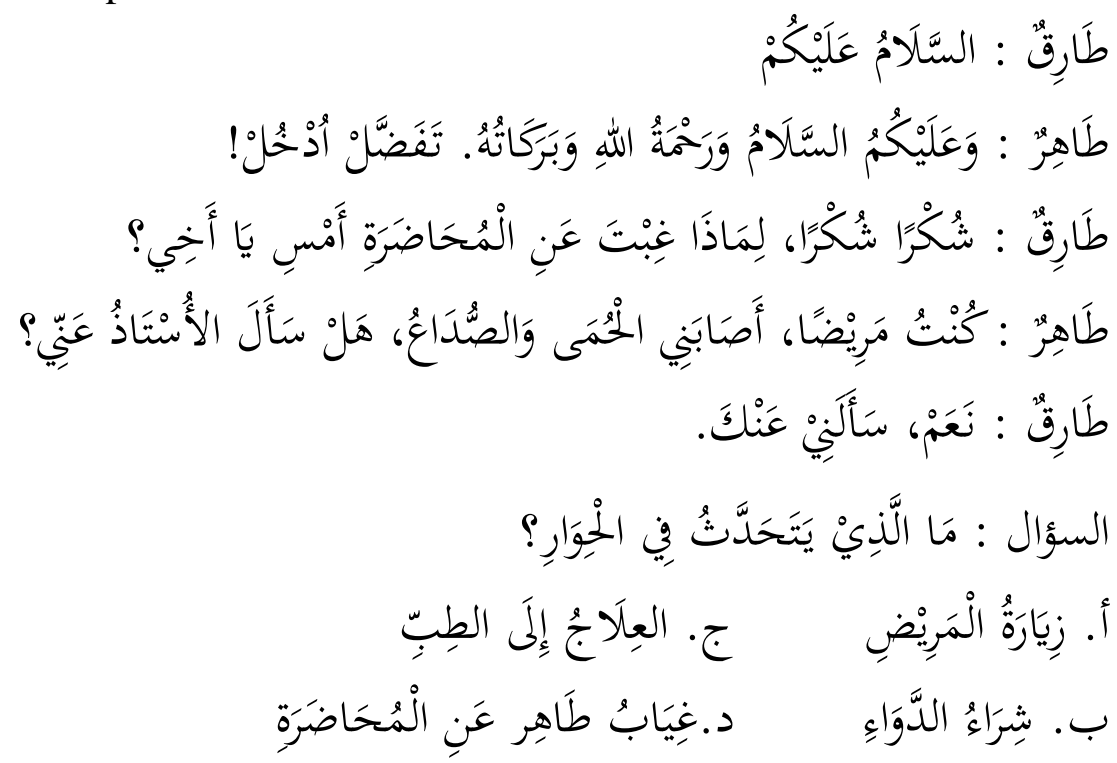

Butir soal diatas menggambarkan pendekatan komunikatif dan pragmatik. Pada soal tersebut, tes digunakan untuk mengukur pemahaman testee terhadap wacana lisan dalam bentuk dialog (menyimak), dengan melihat konteks topik pembicaraan. Menentukan topik pembicaraan dibutuhkan pula pemahaman terhadap bagaimana situasi, dan siapa yang berbicara. Selain komunikatif, tes ini juga menggambarkan pendekatan pragmatik. Tes tersebut meminta testee untuk memilih jawaban yang paling sesuai dengan pertanyaan yang diperdengarkan secara lisan. Butir soal tersebut menanyakan tentang apa yang didialogkan oleh dua orang dalam wacana lisan tersebut.

Contoh lain yang menggambarkan pendekatan komunikatif dan pragmatik seperti soal berikut :

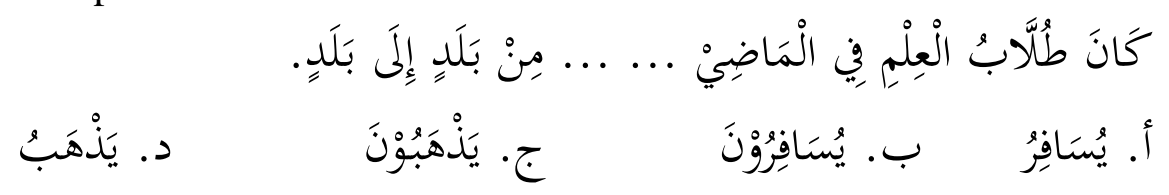

Soal diatas meminta testee untuk melengkapi titik-titik dalam teks dengan memilih kata yang sesuai untuk kalimat tersebut sehingga menjadi kalimat sempurna. Tidak sekedar bagaimana penerapan kaidah nahwiyah secara benar, namun juga mengukur pemahaman testee dalam menggunakan kosakata yang sesuai dengan konteks. Apabila diartikan dalam bahasa Indonesia, kedua kosakata pada pilihan ganda tersebut berarti pergi, namun apabila kita cermati dalam penggunaanya maka akan kita temukan 
perbedaanya. Kata يُنَّنَفِ digunakan untuk konteks bepergian jauh, sedangkan

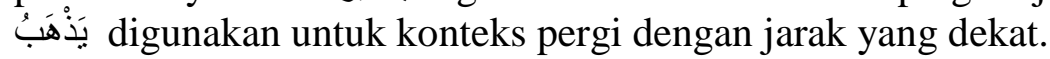

\section{Jenis Tes TOSA}

Dilihat dari segi penyusunannya TOSA termasuk jenis tes standar. TOSA sebagai tes standar maksudnya adalah TOSA sebagai tes dikembangkan oleh suatu Lembaga dalam hal ini adalah Pusat Pengembangan Bahasa IAIN Surakarta dengan standar yang telah ditentukan dan dapat digunakan untuk skala lebih luas tidak hanya sebatas pada satu kelas tertentu. ${ }^{19}$ TOSA bukanlah tes yang disusun oleh masing-masing dosen setelah selesai perkuliahan. Hal ini juga dapat dilihat dari kriteria-kriteria tes standar yang terdapat pada TOSA, yaitu 1) mengukur aspek tertentu (bahasa Arab), 2) dilaksanakan pada kondisi standar yang sama (cara dan waktu), 3) mempunyai validitas, reliabilitas dan objektivitas yang berkadar tinggi, 4) memiliki standar dan konsisten, 4) berlaku pada individu khalayak umum. ${ }^{20}$

Tes standar dalam hal ini adalah TOSA digunakan untuk mengukur kompetensi Bahasa Arab mahasiswa yang hasilnya dapat memberikan prediksi terhadap kesuksesan mahasiswa dalam studi baik jenjang sarjana maupun magister yang salah satunya Bahasa arab sebagai salah satu Bahasa yang digunakan untuk memahami referensi-referensi berbahasa Arab. Karena TOSA sebagai tes yang berfungsi untuk mengukur kompetensi mahasiswa dalam Bahasa Arab, maka ia harus memiliki validitas dan reliabilitas yang dapat diukur dengan analisis validitas dan reliabilitas. ${ }^{21}$ Analisis kualitas tes harus dilakukan setelah tes selesai dibuat untuk mengetahui derajat kualitas tes, baik tes secara keseluruhan maupun butir soal yang menjadi bagian tes.

Dalam menentukan standar soal tes dapat melihat standar yang dikembangkan oleh para ahli Bahasa. Diantara standar kompetensi Bahasa yang dikembangakan oleh para ahli Bahasa yaitu Al-Ithar Al-Marja'i AlEropa Al-Musytarak atau biasa disingkat dengan CEFR (Common European Framework of Reference for Language), Ma'ayiir Al-Majlis Al-Amriki Li AlLughaat atau ACTFL (American Council for the Teaching of Foreign Languages), dan Ma'aayiiru At-Thaawilah Al-Mustadirah atau ILR (Interagency Language Roundtable). Setiap lembaga tersebut berbeda-beda dalam membagi tingkatan-tingkatan kompetensi berbahasa. Dalam tulisan Tulus Musthofa tentang Al-Ithaar Al-Marja'iy Al-Induniisiy Li Ta'liimi AlLughah Al-'Arabiyyah Fi Dhaui Al-Ithar Al-Marja'iy Al-Iroba Al-Musytarak

${ }^{19}$ Wina Sanjaya, Kurikulum dan Pembelajaran : Teori dan Praktik Pengembangan Kurikulum Tingkat Satuan Pendidikan (KTSP) (Jakarta: Kencana, 2015), 356.

${ }^{20}$ Muri Yusuf, Asesmen dan Evaluasi Pendidikan : Pilar Penyedia Informasi dan

Kegiatan Pengendalian Mutu Pendidikan (Jakarta: Kencana, 2017), 100.

${ }^{21}$ Sanjaya, Kurikulum dan Pembelajaran : Teori dan Praktik Pengembangan Kurikulum Tingkat Satuan Pendidikan (KTSP), 356. 
Li Ta'limi Al-Lughaat menjelaskan bahwa terdapat banyak tingkatan kompetensi Bahasa yang dikembangkan oleh lembaga Bahasa, yang berbeda antara satu lembaga Bahasa dengan lembaga Bahasa lainnya baik tingkat local, regional, nasional, dan bahkan internasional dalam menentukan tingkatan kompetensi Bahasa. CEFR membagi kompetensi bahasa menjadi 3 tingkatan (mubtadi', mutawasith, mutaqaim), dan setiap tingkatan memiliki 2 tingkatan seperti berikut : A1, A2, B1, B2, C1, C2. Sedangkan ACTFL membagi kompetensi bahasa menjadi 5 tingkatan, yaitu mubtadi, mutawasith, mutaqadim, mutafawiq, mutamayiz, dan setiap tingkatan untuk mubtadi', mutawasith, mutaqadim dibagi menjadi 3, yaitu adna, awsath, a'laa. Sedangkan untuk kerangka tingkat kompetensi bahasa Arab yang diusulkan oleh lembaga Bahasa Arab Saudi, yaitu ta'sis, mubtadi', mutawasith, mutaqadim, mutaqadim, mutamayiz. ${ }^{22}$ Secara rinci dapat dilihat pada tabel di bawah ini:

Tabel Kompetensi Bahasa

\begin{tabular}{|c|c|c|c|c|}
\hline \multicolumn{2}{|c|}{$\begin{array}{c}\text { Mustawiyyat } \\
\text { Al-Majlis Al-Amriki }\end{array}$} & \multirow{2}{*}{$\begin{array}{c}\begin{array}{c}\text { Mustawiyat } \\
\text { Al-Ithar Al-Eropa }\end{array} \\
\text { A1 }\end{array}$} & \multicolumn{2}{|c|}{$\begin{array}{c}\text { Mustawiyat } \\
\text { Al-Ithar Al-Arabiy }\end{array}$} \\
\hline Mubtadi' & $\begin{array}{c}\text { Adna } \\
\text { Awsat } \\
\text { A'la }\end{array}$ & & Ta'siis A1 & $\begin{array}{c}\text { Adna } \\
\text { Awsat } \\
\text { A'la }\end{array}$ \\
\hline Mutawasith & $\begin{array}{c}\text { Adna } \\
\text { Awsat } \\
\text { A'la }\end{array}$ & $\mathrm{A} 2$ & Mubtadi' A2 & $\begin{array}{c}\text { Adna } \\
\text { Awsat } \\
\text { A'la }\end{array}$ \\
\hline Mutaqadim & $\begin{array}{c}\text { Adna } \\
\text { Awsat } \\
\text { A'la }\end{array}$ & B1 & Mutawasith B1 & $\begin{array}{c}\text { Adna } \\
\text { Awsat } \\
\text { A'la }\end{array}$ \\
\hline Mutafawiq & & B2 & Mutaqadim B2 & $\begin{array}{l}\text { Adna } \\
\text { Awsat }\end{array}$ \\
\hline & & $\mathrm{C} 1$ & Mutaqadim C1 & A'la \\
\hline Mutamayiz & & $\mathrm{C} 2$ & Mutamayyiz C1 & \\
\hline
\end{tabular}

Apabila dilihat dari tujuannya tes dapat diklasifikasikan menjadi lima, yaitu : achievement test, proficiency test, diagnostic test, placement test, dan aptitude test. Setiap tes dari kelima tes tersebut memiliki tujuan yang berbeda-beda. Achievement test atau tes pencapaian belajar adalah tes yang secara langsung berkaitan dengan tujuan mata pelajaran atau materi yang diajarkan. Proficiency test atau tes kemahiran adalah tes yang digunakan untuk melihat kemahiran seseorang dalam bahasa tertentu. Diagnostic test sesuai namanya merupakan tes yang digunakan untuk mendiagnosis aspek

${ }^{22}$ Musthofa, "Al-Ithaar Al-Marja'iy Al-Induniisiy Li Ta'liimi Al-Lughah Al-'Arabiyyah Fi Dhaui Al-Ithar Al-Marja'ly Al-Eropa Al-Musytarak Li Ta'limi Al-Lughaat." 
khusus dari unsur bahasa. Dengan tes diagnosis ini akan diketahui hal-hal yang menjadi kesulitan peserta didik dari unsur bahasa yang dimaksud.

Placement test atau tes penempatan merupakan tes yang dilakukan sebelum program atau kegiatan pembelajaran dilakukan yang bertujuan untuk mengelompokan peserta didik sesuai dengan kemampuannya. Sedangkan tes bakat adalah tes yang digunakan untuk memprediksi kemampuan seseorang dalam bahasa asing. Menurut brown ada dua tes yang dipandang baku untuk tes bakat ini, yaitu tes yang dikembangkan oleh carrol dan spon (1958) yang diberi nama Modern Language Aptitude Test (MLAT) dan tes yang dikembangkan oleh Pimsleur (1966) yang diberi nama Pimsleur Language Aptitude Battery (PLANB). ${ }^{23}$

Dilihat dari tujuan tes, TOSA merupakan bagian dari tes profisiensi. TOSA sebagai tes profisiensi adalah TOSA sebagai tes yang digunakan untuk menguji kompetensi dan keterampilan seseorang terhadap suatu Bahasa secara umum. Sehingga tes ini bukanlah tes yang dilaksanakan untuk mengukur keberhasilan suatu pembelajaran yang terkait dengan kurikulum.

\section{Model Soal TOSA dan Tingkatannya Berdasarkan CEFR}

Model soal memiliki peran sangat penting dalam menentukan kesuksesan sebagai alat ukur. Terlebih Bahasa, sebagai pelajaran yang memiliki karakteristik yang berbeda dengan pelajaran lain, karena Bahasa merupakan kompetensi atau keterampilan, bukan sekedar pengetahuan. Tes Bahasa setidaknya bertujuan untuk mengukur dua hal, yaitu pertama, mengukur penguasaan Bahasa yang bersifat teoritis dengan melihat Bahasa sebagai satu sistem yang terstruktur. Kedua, mengukur Bahasa yang bersifat praktis dengan melihat bagaimana seseorang dapat berkomunikasi dengan Bahasa tersebut. ${ }^{24}$ Dua hal ini yang kemudian menjadi dasar komponenkomponen soal tes yang disusun. Pada soal TOSA misalnya, soal-soal yang disusun digunakan untuk mengukur kemampuan testee dalam memahami dan menggunakan Bahasa Arab dalam berbagai situasi dengan kaidah nahwiyah (sintaksis) dan sharfiyyah (morfologis) yang benar.

Dalam mengukur kompetensi Bahasa, selain alat ukur yang penting harus dilakukan adalah menetapkan standar kompetensi Bahasa. Dengan standar yang telah ditetapkan tersebut maka akan menjadi jelas skor yang diperoleh merupakan gambaran dari kompetensi testee. Dalam menetapkan standar tentu tidak bisa sesukanya dalam menentukan, lebih-lebih TOSA sebagai tes standar, maka harus mengacu pada standar-standar yang dikembangkan oleh ahli Bahasa maupun lembaga-lembaga pengembangan

\footnotetext{
${ }^{23}$ Tim Pengembang Ilmu Pendidikan, IImu dan Aplikasi Pendidikan (Jakarta: Imperial Bhakti Utama, 2007), 104.

${ }^{24}$ Rina Suci Andriani, "Tes Kebahasan," Educate 3, no. 2 (2014), http://journal.unipdu.ac.id:8080/index.php/educate/article/view/642.
} 
Bahasa yang telah diakui oleh masyarakat internasional. Dalam penelitian Azkia Muharom Albantani menyebutkan bahwa Rusydi Ahmad Thu'aimah membagi kompetensi Bahasa seseorang menjadi beberapa tingkatan baik dari segi unsur kebahasaan maupun keterampilan berbahasa. ${ }^{25}$ Ketentuan ini bisa menjadi salah satu referensi dalam mengembangkan standar kompetensi Bahasa Arab sebagai acuan dalam mengembangkan TOSA.

Sebagaimana dijelaskan pada sub bab sebelumnya, ada beberapa lembaga Bahasa di belahan dunia yang telah mengembangakn pelevelan kompetensi Bahasa yang kemudian dijadikan acuan dalam mengembangkan tes standar, seperti $C E F R$. Diantara tes Bahasa yang mengacu pada $C E F R$ yaitu Cambridge English Language Assessment, International English Language Testing System (IELTS), Test of English for International Communication (TOEC or TOEIC), Test de français international (TFI), Test d'Évaluation du Français (TEF), Diplôme d'études en langue française $(D E L F)$, dan Diplôme approfondi de langue française $(D A L F) .{ }^{26}$

$C E F R$ sendiri merupakan standar internasional untuk menggambarkan kompetensi Bahasa seseorang. CEFR berangkat dari satu kebutuhan untuk mendefinisikan dan mengukur tingkat kemahiran bahasa dengan adanya kesepakatan di antara berbagai stakeholders di bidang pendidikan bahasa kedua atau bahasa asing pada tingkat nasional dan internasional. Tujuan CEFR adalah untuk membantu stakeholders untuk menjelaskan tingkat kemahiran yang dibutuhkan oleh standar, tes, dan ujian yang ada, untuk memfasilitasi perbandingan antara berbagai sistem kualifikasi.

CEFR menetapkan enam level kompetensi seseorang dalam berbahasa asing, yaitu 1) Beginner atau A1;2) Elementary atau A2;3) Intermediate atau B1; 4) Upper intermediate atau B2; 5) Advanced atau C1; dan 6) Proficient atau C2. Setiap level menggambarkan kualifikasi kemampuan berbahasa yang telah ditetapkan dalam CEFR. Kualifikasi-kualifikasi tersebut kemudian diterjemahkan dalam bentuk soal tes.

Pada level A1 atau Mustawa Mubtadi' Awal (Beginner) kompetensi yang harus dikuasai yaitu :

a. Memahami dan menggunakan ekspresi berbahasa sehari-hari dan ungkapan-ungkapan yang sangat dasar yang dirancang untuk memenuhi kebutuhan komunikasi yang sangat terbatas.

b. Mampu memperkenalkan diri sendiri dan orang lain, misalnya melakukan kegiatan tanya jawab dengan pertanyaan yang rinci tentang seseorang

\footnotetext{
${ }^{25}$ Azkia Muharom Albantani, “Mustawayat Ta'alum Wa Ta'lim Al-Lughah Al'Arabiyah 'Inda Rusydi Ahmad Thu'aimah," Arabiyat : Jurnal Pendidikan Bahasa Arab dan Kebahasaaraban 1, no. 1 (2014): 137, https://doi.org/10.15408/a.v1i1.1135.

${ }^{26}$ Assessment, the CEFR and the Role of International Exams, diakses 20 Mei 2020, www.caslt.org.
} 
seperti dimana ia tinggal, orang-orang yang mereka kenal, dan hal-hal yang ia miliki.

c. Mampu berinteraksi dengan cara yang sederhana dalam percakapan dengan orang lain secara perlahan dan jelas.

Dan pada level A2 atau Mustawa Mubtadi' Tsaniy (Elementary) kompetensi yang harus dikuasai yaitu :

a. Memahami kalimat dan frase yang sering digunakan pada keseharian seperti informasi dasar tentang diri sendiri, keluarga, belanja dan geografi lokal.

b. Berkomunikasi dalam topik sederhana dan rutin yang membutuhkan pemahaman yang sederhana dan langsung mengenai hal-hal yang akrab dan rutin.

c. Menjelaskan secara sederhana tentang kepribadian dan lingkungan sekitarnya serta hal-hal kebutuhan yang mendesak.

Sedangkan pada level B1 atau Mustawa Mutawasith Tsalits

(Intermediate) kompetensi yang harus dikuasai yaitu :

a. Memahami point utama dari point utama dari hal-hal yang akrab dan jelas, seperti bisnis, liburan dan sekolah.

b. Mengatasi situasi yang paling mungkin timbul saat bepergian didaerah dimana ia berbicara Bahasa tersebut.

c. Menulis teks sederhana tentang tema-tema yang sudah akab atau pribadi.

d. Menjelaskan tentang pengalaman , peristiwa, impian, harapan, dan citacita secara singkat dan memberikan alasan serta penjelasannya.

Dan pada level B2 atau Mustawa Mutawasith Rabi' (Upper intermediate) kompetensi yang harus dikuasai yaitu :

a. Memahami ide utama teks yang kompleks baik berupa topik yang abstrak atau yang spesifik, termasuk diskusi tentang bidang tertentu.

b. Berkomunikasi dengan tingkat kelancaran dan spontanitas yang membuat komunikasi teratur dengan penutur asli tanpa jeda dari salah satu pihak.

c. Menghasilkan teks yang rinci dan jelas pada berbagai topik dan menjelaskan sudut pandangnya pada isu topical serat memberikan komentar kelebihan dan kekurangan dilihat dari berbagai aspek.

Sedangkan pada level C1 atau Mustawa Mutaqadim Khamis (Advanced) kompetensi yang harus dikuasai yaitu :

a. Memahami berbagai teks panjang dan mencari menganalisis makna yang tersembunyi.

b. Mengekspresikan dirinya dengan lancar dan secara spontan tanpa mencari banyak penjelas dengan berbagai ungkapan.

c. Menggunakan Bahasa secara fleksibel dan efektif untuk tujuan sosial, akademik, dan pekerjaan. 
d. Menghasilkan teks yang memberikan informasi yang jelas, terorganisir dengan baik dan rinci pada tema yang kompleks, menunjukan penggunaan pola yang terstruktur dan komunikatif.

Dan pada level tertinggi yaitu C2 atau Mustawa Mutaqadim Sadis (Proficient) kompetensi yang harus dikuasai yaitu :

a. Memahami dengan mudah semua yang didengar dan dibaca.

b. Meringkas informasi dari berbagai sumber, baik dengan menulis, berbicara, dan mempresentasikan dengan bentuk yang koheren.

c. Mengekspresikan dirinya secara otomatis dan khusus dengan membedakan secara rinci makna dari suatu kasus yang paling kompleks. ${ }^{27}$

Dari uraian diatas jika diperhatikan secara seksama maka dapat dipahami bahwa CEFR berisi skema deskriptif yang mencakup kebahasaan, keterampilan berbahasa dan kosakata disajikan bersamaan sebagai satu kesatuan dengan mempertimbangkan tingkat kognitif, emosional, dan sosial budaya. ${ }^{28}$

Untuk menggunakan CEFR sebagai acuan dalam penyusunan tes Bahasa maka dibutuhkan penetapan indikator yang dikembangkan dari uraian deskriptif level CEFR sebagaimana disebutkan diatas dengan menyesuaikan model tes yang akan dikembangkan. Pada TOEFL misalnya, didalamnya hanya mencakup tiga komponen tes yaitu listening comprehension, structure and written expression, dan reading comprehension. Untuk mengembangkan soal dari tiga komponen tersebut dengan mengacu pada CEFR maka penafsiran terhadap $C E F R$ diperlukan sehingga tes yang dikembangkan benar-benar menggambarkan level sebagaimana yang dimaksud dalam CEFR. ${ }^{29}$

Untuk melihat pada tingkatan apa soal TOSA disusun mengacu pada CEFR maka perlu dipaparkan terlebih dahulu bagian-bagian soal TOSA. Soal TOSA terdiri dari tiga bagian.yaitu fahmu al-masmu', Fahmu At-Tarkib Al-Lughawiyyah, dan fahmu al-maqru'. Apabila dilihat dari unsur-unsur yang terdapat pada soal TOSA maka dapat dipahami bahwa TOSA mencakup 2 hal, yaitu tes kompetensi kebahasaan dan kompetensi berbahasa.

${ }^{27}$ University of Cambridge ESOL Examinations, Using the CEFR: Principles of Good Practice (Cambridge: Cambridge ESOL, 2011), https://www.cambridgeenglish.org/images/126011-using-cefr-principles-of-goodpractice.pdf.

${ }^{28}$ Ruliana Khasanah, "Kerangka Pengajaran Bahasa Asing Level A1-A2 Dalam Standar CEFR (Studi Pendekatan Filsafat Bahasa)" (Tesis, UIN Sunan Kalijaga, 2019), http://digilib.uin-suka.ac.id/37705/.

${ }^{29}$ Contoh dalam tes Bahasa inggris dapat dilihat di https://ezoteriker.ru/id/urovniznaniya-angliiskogo-yazyka-cefr-principy-opisanie-primery/, diakses pada tanggal 21 Mei 2020. Dalam konteks pengembangan TOSA maka juga perlu penafsiran sesuai dengan karakteristik bahasa Arab. 
Kompetensi kebahasaan merupakan pengetahuan seseorang terkait dengan sistem bahasa yang meliputi struktur, kosakata, dan seluruh aspek bahasa lainnya yang saling berhubungan. Kompetensi kebahasaan sangat penting dikuasai oleh seseorang karena akan berpengaruh terhadap kompetensi bahasanya. Sehingga tes kompetensi kebahasaan merupakan tes yang dimaksudkan untuk mengetahui penguasaan seseorang terhadap sistem bahasa, struktur bahasa, kosakata, dan seluruh aspek kebahasaan yang saling terkait. ${ }^{30}$ Tes kompetensi kebahasaan yang ditampilkan pada soal TOSA bukanlah soal dalam bentuk tes pengetahuan, diskrit, terisolasi dan belum berfungsi komunikatif, sebaliknya tes kompetensi kebahasaan yang ditampilkan pada soal TOSA merupakan kompetensi kebahasaan yang bersifat komunikatif yaitu struktur dan kosakata yang dilibatkan dalam wacana, baik wacana lisan (menyimak) maupun wacana tertulis (membaca dan menulis).

Bagian Fahmu Al-masmu' merupakan soal tes TOSA menguji kemampuan peserta tes dalam mendengarkan pembicaraan atau memahami bahasa lisan berbahasa Arab. Bagian fahmu al-masmu' pada TOSA terdiri dari 25 soal dengan pembagian empat jenis soal, yaitu an-Naw' al-Awwal, an-Naw' ats-Tsani, an-Naw' ats-Tsalis dan an-Naw' ar-Rabi'.

Pada an-naw' al-awwal soal berbentuk audio yang diperdengarkan berbentuk ujaran atau ungkapan sederhana kemudian peserta tes diminta memberikan respon yang tepat dari ujaran yang didengarkannya, seperti ungkapan memberikan salam, selamat datang, pertemuan, perpisahan, dan ungkapan-ungkapan pendek lainnya. Sedang pada An-Naw' Ats-Tsaniy soal berbentuk audio khiwar (dialog) singkat diperdengarkan kemudian peserta tes diminta untuk menjawab pertanyaan yang sesuai dengan konten khiwar, dengan tema-tema seputar kegiatan sehari-hari seperti di rumah, di pasar, di sekolahan, di kantor. Pada bagian An-Naw' Ats-Tsaniy model soal menanyakan tentang konten khiwar yang memungkin bagi testee menjawab dengan mudah karena hanya sebatas mengingat apa yang ia dengar tidak banyak analisis.

Pada An-Naw' ats-Tsalis soal berupa audio khiwar (dialog) panjang yang diperdengarkan kemudian peserta tes diminta untuk menjawab beberapa pertanyaan yang sesuai dengan konten khiwar. Tema-tema yang muncul pada soal An-Naw' ats-Tsalis lebih luas yang meliputi tema-tema pengetahuan yang lebih abstrak seperti pekerjaan, perhotelan, berita dalam kolam, dan wacana-wacana lisan lainnya. Model soal pada An-Naw' atsTsalis tidak banyak berbeda dengan An-Naw' Ats-Tsani yaitu hanya sebatas mengingat konten audio yang diperdengarkan. Perbedaan khiwar pada naw'

${ }^{30}$ Burhan Nurgiyantoro, Penilaian Otentik Dalam Pembelajaran Bahasa (Yogyakarta: Gadjah Mada University Press, 2018), 41-44. 
tsani dan naw' tsalits pada panjangnya khiwar, apabila pada naw' tsani satu khiwar hanya untuk satu soal, pada khiwar tsalits satu khiwar digunakan untuk dua sampai empat soal. Sedangkan pada An-Naw' ar-Rabi' soal berupa audio pidato atau teks yang diperdengarkan kemudian testee diminta untuk menjawab beberapa pertanyaan yang sesuai dengan konten teks audio. Tema-tema pada An-Naw' ar-Rabi' berupa pengetahuan-pengetahuan yang lebih abstrak, seperti misalnya kabar berita, sejarah, dan pengetahuan keislaman.

Audio pada fahmul masmu' TOSA bersumber dari rekaman tim P2B IAIN Surakarta, bukan suara native speaker arab, yang tentu memiliki keakuratan yang berbeda dengan suara native asli, baik dari tempo maupun lahjahnya. Sedangkan apabila dianalisis berdasarkan cakupan materi dan model soal pada fahmul masmu', maka dapat disimpulkan bahwa level soal fahmul masmu' pada TOSA setara dengan A1- C1 CEFR, yang dituangkan pada keempat bagian pada soal fahmul masmu'.

Bagian kedua dari soal TOSA yaitu Fahmu At-Tarkib Al-Lughawiyyah. Soal Fahmu At-tarakib Al-Lughawiyyah yang terdapat pada TOSA (Test of Standard Arabic) bertujuan untuk menguji kemampuan dalam mengidentifikasi Bahasa Arab tulis yang digunakan dalam situasi formal. Dalam komunikasi tulis tentu berbeda dengan komunikasi lisan, karena apa yang diterima melalui ekspresi komunikasi lisan belum tentu lazim diterima dalam komunikasi tulis. Dengan demikian, kemampuan testee akan diuji untuk menentukan kalimat yang paling tepat dan benar dalam pengungkapannya dalam bahasa tulis, sehingga pengetahuan yang memadai tentang qawaid al-lughah al-'arabiyyah (kaidah Bahasa Arab) meliputi syigah kalimah (bentuk kata), penguasaan kosakata dan tarakibu al kalimat fi al jumlah (susunan kata dalam kalimat) sangat diperlukan untuk mengetahui bagaimana susunan huruf, sehingga membentuk kata yang tepat dan sesuai dengan makna yang diinginkan, menyusun sebuah kata hingga menjadi kalimat yang benar dan mudah mengidentifikasi kesalahankesalahan pada kalimat tersebut.

Pada bagian fahmu at-tarakib al-lughawiyah pada TOSA terdapat dua model soal, yaitu takmilu al-jumlah (melengkapi kalimat) dan tahlilu alakhtha' (analisis kesalahan). Pada soal takmilu al-jumlah (melengkapi kalimat) berupa kalimat yang belum lengkap, dan testee diminta untuk melengkapi kalimat tersebut dengan memilih kata yang sesuai dan benar menurut kaidah Bahasa Arab. Sedangkan pola kedua pada soal fahmu tarakib al-lughawiyyah berupa tahlilul akhtha' atau analisis kesalahan. Pola soal pada bagian ini berupa kalimat dengan beberapa kata yang dalam kalimat tersebut telah digaris bawahi dan testee diminta untuk menganalisis kata yang salah dari segi qawaid al-'arabiyyah. 
Model soal pada fahmu at-tarakib al-lughawiyyah mengukur kompetensi testee dalam memilih kosakata yang tepat untuk mengungkapkan suatu hal yang sesuai dengan konteks kalimat yang diinginkan yang berkaitan dengan sosiolinguistik. Walaupun begitu hanya sedikit soal yang mengukur hal itu, kebanyakan soal masih didominasi soal-soal yang mengukur kompetensi menulis dalam mempraktikan sintaksis dan morfologis. Tidak banyak soal yang mengukur kemampuan menulis yang lebih komplek seperti menuangkan gagasan, eksposisi, dan argumentasi pada tulisan. Gramatikal yang diujikan pada soal juga masih dasar belum sampai pada perpaduan antar kaidah. Hal ini menunjukan bahwa pada bagian ini apabila mengacu pada CEFR maka standar soal fahmu tarakib pada TOSA setara dengan level A1 sampai B2 CEFR.

Bagian ketiga pada soal TOSA adalah fahmu al-maqru', yaitu salah satu bagian dari TOSA (Test of Standard Arabic) yang bertujuan untuk menguji kemampuan mahasiswa dalam memahami, menganalisis dan menyimpulkan teks berbahasa Arab. Tema-tema yang diujikan pada bagian ini diantaranya tentang keluarga, aktivitas sehari-hari, di sekolah, di tempat kerja, pekerjaan, hobi, Pendidikan, dan bacaan-bacaan lainnya yang berkaitan dengan budayaperadaban Arab dan keislaman.

Model soal pada Fahmu Al-maqru' memiliki beberapa pola, diantaranya yaitu 1) Ta'yiin Maudhu'u An-Nash (mengetahui tema bacaan), yaitu salah satu jenis soal dalam Fahm al-al-Maqru' yang mengukur kompetensi testee dalam memahami teks bacaan dengan menentukan topik atau judul suatu bacaan; 2) Al-fikrah ar-raisiyyah (mengetahui ide pokok bacaan), yaitu model soal untuk mengukur kompetensi testee dalam memahami keseluruhan teks pada satu paragraf dengan menentukan ide pokok atau gagasan pada suatu paragraf; 3) Marjau al-kalimah, yaitu jenis soal untuk mengukur kompetensi testee dalam memahami kalimat yang menggunakan kata ganti maupun kata tunjuk yang berkaitan dengan kalimat sebelumnya; 4) Istinbathu Al-kalimah, yaitu model soal yang mengukur kompetensi testee dalam memahami teks bacaan dengan menggali informasi baik yang tertuang secara implisit maupun eksplisit; 5) Al-ma'lumat Al-mufashsholah, yaitu jenis pertanyaan yang menanyakan mengenai informasi tertentu yang terdapat dalam bacaan, tidak menanyakan isi secara keseluruhan.

Berdasarkan model dan cakupan tema bacaan yang beragam pada soal fahmul maqru' TOSA, pada dapat disimpulkan standar kompetensi membaca pada TOSA mengacu pada level CEFR setara dengan B1-C1. Secara keseluruhan standar kompetensi yang terdapat pada soal TOSA disandingkan dengan standar CEFR dapat dilihat pada tabel dibawah ini: 
Tabel Standar Kompetensi TOSA berdasarkan Standar CEFR

\begin{tabular}{cccc}
\hline Level CEFR & $\begin{array}{c}\text { Fahmul } \\
\text { Masmu }\end{array}$ & $\begin{array}{c}\text { Fahmu } \\
\text { At-Tarakib } \\
\text { Al-Lughawiyyah }\end{array}$ & Fahmul Maqru, \\
\hline A1 & $\sqrt{ }$ & $\sqrt{ }$ & - \\
A2 & $\sqrt{ }$ & $\sqrt{ }$ & - \\
B1 & $\sqrt{ }$ & $\sqrt{ }$ & $\sqrt{ }$ \\
B2 & $\sqrt{ }$ & & $\mathrm{V}$ \\
C1 & $\mathrm{V}$ & & \\
C2 & & & \\
\hline
\end{tabular}

Dari tabel diatas maka dapat kita lihat bahwa standar kompetensi setiap bagian pada TOSA dilihat dari perspektif CEFR memiliki tingkatan yang berbeda-beda. Hal ini berarti, soal TOSA yang dikembangkan sebagai alat ukur akan menjadi kurang valid apabila penskoran hasil tes merupakan hasil kumulatif dari 3 bagian tersebut. Soal yang baik tentu memiliki bobot standar yang sama pada setiap bagian tes.

\section{Kesimpulan}

Berdasarkan analisis model soal TOSA dilihat dari pendekatannya disimpulkan, TOSA merupakan tes dengan pendekatan integratif, komunikatif dan pragmatik. Sedangkan berdasarkan penyusunannya, TOSA termasuk jenis standar. Secara keseluruhan penyusunan soal TOSA belum mengacu pada standar kompetensi yang telah dikembangkan dan disepakati oleh salah satu ahli Bahasa di dunia. Standar kompetensi TOSA masih menggunakan standar lokal yang ditetapkan oleh tim penyusun soal PPB IAIN Surakarta. Tentu hal ini akan bertolak belakang dengan orientasi jangka panjang, apabila TOSA digunakan sebagai tes standar yang dapat mengukur dan menggambarkan kompetensi bahasa Arab testee yang tepat dan jelas. Diharapkan selanjutnya penyusunan soal TOSA harus mengacu pada standar yang telah diakui oleh masyarakat dunia. Dengan menggunakan standar kualifikasi yang diakui oleh dunia internasional dalam penyusunannya yang memudahkan bagi para pihak yang berkepentingan untuk melihat kompetensi bahasa melalui skor hasil tes. Maka dari itu penelitian ini dapat merekomendasikan beberapa penelitian yang dapat dilakukan pada penelitian selanjutnya, diantaranya yaitu pertama, pengembangan standar kompetensi Bahasa arab untuk tes standar. Kedua, pengembangan soal TOSA sebagai tes standar yang mengacu pada kompetensi standar Bahasa yang diakui oleh internasional. 


\section{Daftar Pustaka}

Ainin, Moh. "Kesahihan Dalam Penyusunan Tes Bahasa Arab Di Madrasah/Sekolah." Prosiding Konferensi Nasional Bahasa Arab 2 (2016). http://prosiding.arabum.com/index.php/konasbara/article/view/75.

Albantani, Azkia Muharom. "Mustawayat Ta'alum Wa Ta'lim Al-Lughah Al-

'Arabiyah 'Inda Rusydi Ahmad Thu'aimah." Arabiyat : Jurnal

Pendidikan Bahasa Arab dan Kebahasaaraban 1, no. 1 (2014): 137.

https://doi.org/10.15408/a.v1i1.1135.

Alderson, J. Charles, Neus Figueras, Henk Kuijper, Guenter Nold, Sauli

Takala, dan Claire Tardieu. "Analysing Tests of Reading and Listening in Relation to the Common European Framework of Reference: The Experience of The Dutch CEFR Construct Project." Language

Assessment Quarterly 3, no. 1 (2006): 3-30. https://doi.org/10.1207/s15434311laq0301_2.

Andriani, Rina Suci. "Tes Kebahasan." Educate 3, no. 2 (2014).

http://journal.unipdu.ac.id:8080/index.php/educate/article/view/64 2.

Arikunto, Suharsini. Prosedur Penelitian: Suatu Pendekatan Praktik. Jakarta: Rineka Cipta, 2013.

Bérešová, Jana. "The Impact of the CEFR on Teaching and Testing English in the Local Context." Theory and Practice in Language Studies 7, no. 11 (2017): 959. https://doi.org/10.17507/tpls.0711.03.

Council of Europe. "Common European Framework of Reference for Languages: Learning, Teaching, Assesment." Language Policy Unit, Strasbourg. Diakses 23 Desember 2020.

https://rm.coe.int/16802fc1bf.

Djiwandono, M. Soenardi. Tes Bahasa Dalam Pengajaran. Bandung: ITB Press, 1996.

Faishol, Abdullah. Al-Mahir fi Tathbiqi Maharati al-Istima' wa al-Kalam. Surakarta: P2B IAIN Surakarta, 2019.

Hamzah, Amir. Metode Penelitian Kepustakaan. Malang: Literasi Nusantara, 2020.

Harsch, Claudia, dan Johannes Hartig. "What Are We Aligning Tests to When We Report Test Alignment to the CEFR?" Language Assessment Quarterly 12, no. 4 (2015). https://doi.org/10.1080/15434303.2015.1092545. 
Khasanah, Ruliana. "Kerangka Pengajaran Bahasa Asing Level A1-A2 Dalam Standar CEFR (Studi Pendekatan Filsafat Bahasa)." Tesis, UIN Sunan Kalijaga, 2019. http://digilib.uin-suka.ac.id/37705/.

Munip, Abdul. Penilaian Pembelajaran Bahasa Arab. Yogyakarta: FITK UIN Sunan Kalijaga, 2017.

Muradi, Ahmad. Pembelajaran Menulis Bahasa Arab : Dalam Perspektif Komunikatif. Jakarta: Kencana, 2015.

Musthofa, Tulus. "Al-Ithaar Al-Marja'iy Al-Induniisiy Li Ta'liimi Al-Lughah Al-

'Arabiyyah Fi Dhaui Al-Ithar Al-Marja'ly Al-Eropa Al-Musytarak Li Ta'limi Al-Lughaat." Prosiding Pertemuan IImiah Internasional Bahasa Arab XI (2018).

http://prosiding.imla.or.id/index.php/pinba/article/view/98.

Nurgiyantoro, Burhan. Penilaian Otentik Dalam Pembelajaran Bahasa.

Yogyakarta: Gadjah Mada University Press, 2018.

Sanjaya, Wina. Kurikulum dan Pembelajaran : Teori dan Praktik

Pengembangan Kurikulum Tingkat Satuan Pendidikan (KTSP).

Jakarta: Kencana, 2015.

Tim Pengembang Ilmu Pendidikan. Ilmu dan Aplikasi Pendidikan. Jakarta:

Imperial Bhakti Utama, 2007.

University of Cambridge ESOL Examinations. Using the CEFR: Principles of

Good Practice. Cambridge: Cambridge ESOL, 2011.

https://www.cambridgeenglish.org/images/126011-using-cefr-

principles-of-good-practice.pdf.

Wahab, Muhbib Abdul. Perkembangan Tes Bahasa Arab Standar Di

Indonesia. Jakarta: repository.uinjkt.ac.id, 2017.

http://repository.uinjkt.ac.id/dspace/bitstream/123456789/33917/1 /Muhbib_1.pdf.

Wahab, Muhbib Abdul, Aziz Fahrurrozi, Tulus Musthafa, dan Syamsul Arifin. "Standarisasi Kompetensi Bahasa Arab Bagi Calon Sarjana Perguruan Tinggi Keagamaan Islam Negeri." Arabiyat : Jurnal Pendidikan Bahasa Arab dan Kebahasaaraban 5, no. 1 (2018): 38-64. https://doi.org/10.15408/a.v5i1.6691.

Yusuf, Muri. Asesmen dan Evaluasi Pendidikan : Pilar Penyedia Informasi dan Kegiatan Pengendalian Mutu Pendidikan. Jakarta: Kencana, 2017.

Zaim, M. Evaluasi Pembelajaran Bahasa Inggris. Jakarta: Kencana, 2016. 
190 | Muhammad Zaenuri, Muhammad Nur Kholis, Anisatul Barokah 